\title{
The Benefits of Student-led, Peer-reviewed Journals in Enhancing Students' Engagement with the Academy
}

\section{Introduction}

Universities are under ever-increasing pressure from employers to provide some form of interaction with the professional world, in order to develop student knowledge and to expand their skill sets (Gott, 1995). Academics, meanwhile, are constantly looking for new ways to enhance students' engagement with the Academy. In this context, student-led journals have become increasingly popular ventures in tertiary education over the last number of years, as universities seek to provide students with experiential learning opportunities. Membership of an editorial board of student-led journals is generally undertaken on an extra-curricular basis and generally for curriculum vitae-enhancement purposes (Saunders, 2000). This note, however, details the establishment of a student-led journal as a core element of an MA programme in the National University of Ireland, Galway (NUI Galway). It details the pedagogical context in which and for which the journal was established and assesses the benefits for the students who were involved at editorial level in the publication. Central to the establishment of this journal was the facilitation of the development of independent and critical thinking, innovation, digital literacy and advanced writing skills among the students. Whether or not this was achieved is discussed here as well as the practical steps taken in setting up such a journal.

\section{The NUI Galway student-led journal experience}

The MA (Léann Teanga) (Language Studies) is a one-year master's programme that focuses on the scholarship of the Irish language, with a stream that focuses on translation and another on language planning. The medium of instruction for this MA programme is the Irish language. All the students on the programme take a core module on academic writing. 
It was decided in the academic year 2012-2013 that a compulsory part of this module would be the production of an online journal that would focus on the subject areas taught on the programme, namely translation, language planning, linguistics, sociolinguistics and language teaching. It was felt that this experiential learning opportunity, where students were actively engaged in academic writing and critique would enhance their membership of the Academy.

Five students were involved in the project. They were charged with naming the journal, sending out a call for papers, finding peer-reviewers, liaising with the desk-top publisher, and also writing academic reviews for the journal. These reviews went through the same peer-review process as the other articles that were published. The students named the journal Léann Teanga: An Reiviú ('The Review'). The first part of the title reflects the title of their master's programme while the choice of 'reiviú' reflected that the journal would be a critical academic publication. In total, thirteen articles were published in the journal while Michael D. Higgins, President of Ireland, wrote the introduction, something that underscored the importance of the journal for the students and for the other contributors. (See http://leannteangaanreiviu.oegaillimh.ie/).

There is no doubt that the publication of the Reiviú provided a rich opportunity for experiential education for the students. Experiential education can be defined as 'education...that makes conscious application of the students' experiences by integrating them into the curriculum' (Carver, 2008: 150), while Cantor describes it as 'learning activities that engage the learner directly in the phenomena being studied' (1997: 1). Such educational experiences aim to ensure that the 'learner is directly in touch with the realities being studied' (Keeton and Tate, 1978: 2). The learners, in this instance, were in touch with 
the realities of academic writing, review and publication of scholarly material, central components of the life of the Academy.

\section{Theoretical Rationale}

The decision to introduce the journal as part of the curriculum, with the aim of enhancing student membership of the Academy was underpinned by a number of pedagogical theories discussed below.

\section{Zone of Proximal Development and Scaffolding}

The NUI Galway experiment can be viewed in the context of Vygotsky's zone of proximal development (Tryphon and Voneche, 1996) or 'scaffolding' (Wass et al, 2011), whereby a significant amount of independence was given to the students in the project. Students were given decision-making powers but all student activities were overseen and supported by staff. Students were encouraged to independently undertake tasks with which they were comfortable (writing and word processing, for example), but yet could rely on staff guidance on issues with which they were unfamiliar (peer-review, copyediting). This project, therefore, expanded their knowledge and introduced them to new knowledge experiences. One issue to emphasise in particular is that, unlike many student-led journals, the articles submitted for publication were - to ensure academic rigour - peer-reviewed by academics in the field, rather than by the student editorial board. This decision avoided the criticism of 'inmates truly running the asylum' (Kester, 1986: 14), one that has sometimes been levelled at student-led journals that allow students to review the work of academics.

\section{Apprenticeship and Communities of Practice}

An important learning objective that precipitated the establishment of the NUI Galway journal was the creation of a professional academic identity for the students (Sullivan et al, 
2007). Membership of the editorial board provided an insight into the academic and professional world and acted as a connection between the university and the workplace (Chickering, 1977). When students graduate to a working environment, they must become part of a 'community of practice' (Lave and Wenger, 1991). In order to more easily bridge the gap between student and employee, students must be able to relate theoretical concepts to workplace practices (Gott, 1995). In participating in the journal project at NUI Galway, students were able to see their decontextualised knowledge put into a context of practice and could see the theory they had learned in various modules on their MA programme come to life.

\section{Academic Literacy}

Linked to the notion of an academic identity is the development of academic literacy, allowing one to find an academic voice. Bourdieu, Passeron and de Saint Martin point out that 'Academic language is...no one's mother tongue, not even that of children of the cultivated classes' (1994: 8) while Susan van Schalkwyk (2008: 3) tells us that 'Literacy in an academic connotation is...fluid'. She goes on to quote Ballard, Clanchy and Moore who described academic literacy as a 'compound of linguistic, conceptual and epistemological rules and norms of the academe', but acknowledges that these rules and norms are 'seldom explicit'. The establishment of the Reiviú was an attempt to make these rules explicit to the students on this MA programme. It was a practical attempt to enhance the students' identity as scholars who hold a rightful place in the Academy. Warschauer et al (2004) argue that the promotion of academic literacy involves the creation of social identities for our students, which will enhance their participant status in the academic world. Students, then, 
need to be active participants in the academic world to develop their academic literacy. This was key to the success of the journal in NUI Galway.

Cummins (1991) has also described the necessity of socialisation within the discourse for our students, and argues that this socialisation and identity investment is vital for the student to succeed in academia. Academic literacy, then, is more than the mechanics of writing; it involves the creation of an academic identity for our students and an initiation into the discourse of their area of study.

Many students of the Irish language, the medium of instruction for this MA programme, are not native speakers of Irish. This adds another layer of complexity to the enhancement of academic literacy amongst these students. For such students academic discourse is hugely challenging, and yet, Anna Ní Ghallachair, (2009: 221) emphasising the importance of identity investment in the learning of Irish, says, despite the precarious state of the language, that many people feel a 'gaol ar leith' (a strong affinity) with Irish as their 'own' language. The journal provided a means for our students to find, not only an academic voice, but, for most of them, an academic voice in a language that was not their first tongue.

\section{Benefits of Participation in the Journal}

As part of the project, students were encouraged to think critically and creatively beyond the parameters of the classroom environment and to actively engage with the theoretical knowledge that they had mastered. As Greig (2000: 82) puts it 'Skills such as problem solving, critical thinking, effective communication, teamwork, and organisational, personal and interpersonal relations are not subject specific and complement students' acquisition of professional knowledge.' The students who worked on this journal developed all the skills listed by Greig. They worked as a team, overcame initial feelings of intimidation, and 
mastered the art of compromise. The project helped students learn the mechanics of academic writing - editing, copyediting, formatting, while in a competitive vocational and academic world, our students may have the edge on other students since they actually have an academic publication in the early stages of their academic career. They understand how academic publications work and have confidence about their own participation in the Academy. Indeed, the feedback from the students has been positive and they have described the process as 'very interesting' and as a 'valuable learning experience'. They mentioned that there was more work involved with the journal than they had initially imagined, but nonetheless, they agreed that the experience was worth the effort. From the lecturers' point of view, the benefits of the exercise have informed the decision to maintain the publication of the journal as a core part of this MA programme.

\section{Conclusion}

The production of a journal does have its challenges: time constraints, funding, personality clashes, and, of course, attracting contributors. The benefits, however, far outweigh these challenges. Helen Sword (2009: 319) in her essay 'Writing higher education differently; a manifesto on style' tells us that

...the most effective and engaging academic writers are those who express complex ideas clearly and succinctly; write with originality, imagination and creative flair; convey enthusiasm, commitment and a strong sense of self; tap into a wide range of intellectual interests; avoid excessive jargon; employ plenty of concrete examples and illustrations; demonstrate care for their readers; and know how to tell a good story...

This is what we want for the students of the MA (Léann Teanga) programme, and the journal Léann Teanga: An Reiviú is an important tool in helping them reach this goal and enhancing their membership of the Academy. 


\section{References}

Bourdieu, P., Passeron J.C. and de Saint Martin, M. (1994), Academic Discourse Cambridge: Polity Press

Cantor, J.A. (1997), Experiential Learning in Higher Education: Linking Classroom and Community, ERIC Clearinghouse on Higher Education.

Carver, R. (2008), 'Theory for Practice: A Framework for Thinking about Experiential Education' 3 Philosophical Foundations, 149.

Chickering, A.W. (1977), Experience and Learning: An Introduction to Experiential Learning, Change Magazine Press.

Cummins, J. (1991), 'Conversational and Academic Language Proficiency in Bilingual Contexts', Reading in Two Languages, AILA Review-Revue de I'AILA 8, 75-89.

Gott, S. (1995), 'Rediscovering Learning; acquiring expertise in real-world problem solving tasks', Australian and New Zealand Journal of Vocational Education Research 3(1), 30.

Greig, A. (2000), 'Student-Led Classes and Group Work: A Methodology for Developing Generic Skills', 11 Legal Education Review, 81.

Keeton, M.T. \& Tate, P.J. (1978), 'Editors' Notes: The Boom in Experiential Learning', Morris T. Keeton \& Pamela J. Tate (eds), Learning by Experience: What, Why and How. San Francisco: Jossey-Bass.

Kester, J.G. (1986), 'Faculty Participation in the Student-Edited Law Review', 36 Journal of Legal Education, 14.

Lave, J. \& Wenger, E. (1991), Simulated Learning. Cambridge: Cambridge Press.

Léann Teanga: An Reiviú (2013) http://leannteangaanreiviu.oegaillimh.ie/.

Ní Ghallachair, A. (2009), “'Ciúnas, bóthar, cailín, bainne”: ag filleadh ar an Ghaeilge', Ó Cathain, B. (ed.) Léachtaí Cholm Cille XXXIX, 220-33.

Rodell, F. (1936), 'Goodbye to Law Reviews', 23 Va. L. Rev., 38, 45.

Saunders, N.H. (2000), 'Student-Edited Law Reviews: Reflections and Responses of an Inmate', 49 (6) Duke Law Review, 1163.

Sullivan, W.M., Colby, A., Wegner, J.W., Bond, L. and Schulman, L.S. (2007), Educating Lawyers: Preparation for the Profession of Law. San Francisco: Jossey-Bass.

Sword, H. (2009), 'Writing higher education differently: a manifesto on style', in Studies in Higher Education, 34 (3), 319-36.

Tryphon, A. \& Voneche, J. (1996), Piaget-Vygotsky: The Social Genesis of Thought Hove: Psychology Press.

Van Schalkwyk, S.C. (2008), Acquiring Academic Literacy: A Case of First-Year Extended Degree Programme Students at Stellenbosch University. Dissertation presented for the Degree of Doctor of Philosophy in the Department of Curriculum Studies, Faculty of Education at Stellenbosch University.

Warschauer, M., Grant, D., Del Real, G., and Rousseau, M. (2004), 'Promoting academic literacy with technology: successful laptop programs in K-12 schools' www.elsevier.com/locate/system.

Wass, R., Harland, T. \& Mercer, A. (2011), 'Scaffolding Critical Thinking in the Zone of Proximal Development', 30 (3), Higher Education Research \& Development, 317. 